\author{
V.M. Yurov ${ }^{1}$, V.V. Arkhipov², G.A. Ranova ${ }^{1}$, V.Ch. Laurinas ${ }^{1}$ \\ ${ }^{1}$ Ye.A. Buketov Karaganda State University, Kazakhstan; \\ ${ }^{2}$ G.F. Morozov Voronezh State Forestry University, Russia \\ (E-mail: exciton@list.ru)
}

\title{
Study of dimensional dependencies of thermodynamic characteristics of nanoparticles
}

\begin{abstract}
In the article some approaches to the theoretical description of the deviations of thermodynamic characteristics, such as the heat capacity and the Debye temperature for nanoparticles are considered. The standard Debye inference for the heat capacity of massive crystalline solids was investigated for its modernization in order to take into account surface phenomena of considerable weight for nanoparticles. Unlike massive samples, not only the upper limit of possible frequencies but the lower one starts to matter for nanoparticles. Indeed, in principle, elastic waves with a wavelength greater than the size of the crystal itself cannot arise in a crystal. The equation obtained shows that the thickness of the surface layer of an atomically smooth solid is determined by one parameter - the atomic (molecular) volume of the element, which changes in accordance with the periodic law of D.I. Mendeleev. The equation in its final form, despite its simplicity, shows good agreement with the experimental data
\end{abstract}

Keywords: heat capacity, Debye temperature, nanostructure, crystal, atomic volume.

\section{Introduction}

The beginning of the 21 st century laid the foundation for nanoscience as a whole [1-8]. The main difference from massive crystalline bodies is dimensional factors [9-13]. It is believed that a necessary condition for the manifestation of nanostructured properties of a condensed medium is the size dependence of its physical properties [14]. «Normal» size effects are associated with the contribution of surface energy to Gibbs energy. They are called size effects of the first kind (according to L.M. Scherbakov [15]). Such size effects are characteristic of any systems and are determined by the scattering of quasiparticles (electrons, phonons, etc.) at the boundaries of the system.

Phase size effects (size effects of the second kind) are determined by the entire collective of atoms in the system (collective processes). Such size effects are observed only in nanoclusters and nanostructures [16].

In addition to these classical size effects, there are quantum-size effects [17] associated with the quantization of the energy of charge carriers whose motion is limited in one, two, or three directions. The presence of quantum size effects imposes fundamental restrictions on the use of ultra-small nanoelectronic elements [18]. Quantum-size effects are observed when the size of the structure is comparable with the de Broglie wave $(\sim 0.01-0.1 \mathrm{~nm})$.

In the molecular-kinetic theory of an ideal gas, the concept of temperature is closely related to the concept of thermal equilibrium. Bodies in contact with each other can exchange energy. The energy transferred from one body to another by thermal contact is called the amount of heat. Thermal equilibrium is a state of a system of bodies in thermal contact, in which heat transfer from one body to another does not occur, and all macroscopic parameters of the bodies remain unchanged. Temperature is a physical parameter that is the same for all bodies in thermal equilibrium. The possibility of introducing the concept of temperature follows from experience and is called the zero law of thermodynamics.

In this paper, we consider some approaches to the theoretical description of the deviations of thermodynamic characteristics, such as heat capacity and Debye temperature, for nanoparticles.

\section{Heat capacity of nanoparticles}

The Debye approach to deriving the heat capacity of a crystal is based on calculating the total number of phonons at a given temperature [19]. Namely, if we take into account only the harmonic approximation of the interatomic potential, then the internal energy can be represented as 


$$
U=\sum_{i}\left(N_{i}+\frac{1}{2}\right) h v_{i}
$$

Considering phonons as a gas of boson particles, and taking into account possible degeneracy, we get

$$
U=\sum_{i}\left(\frac{1}{\exp \left(h v_{i} / k T\right)-1}+\frac{1}{2}\right) g_{i} h v_{i} .
$$

In contrast to the photon gas, in this amount there is an upper limit on the frequency due to the size of the atom. In order of magnitude, this limit should be equal to $v_{\max }=u / d$, where $u$ is the phase velocity of the waves in the crystal, $d$ is the size of the unit cell. More precisely, the limiting frequency is sought from the equality of the total number of phonons $N_{i} h v_{i}$ to the number of vibrational degrees of freedom of the crystal $3 N-6 \approx 3 N$. Moving from the summation over frequencies to the integration according to the standard scheme, we obtain the following expression for the maximum frequency and the characteristic Debye temperature $\theta=h v_{\max } / k_{B}$.

$$
v_{\max }=u \sqrt[3]{\frac{3 N}{4 \pi V}}, \theta=\frac{h u^{3}}{k_{B}} \sqrt[3]{\frac{3 N}{4 \pi V}} .
$$

The problem of the need for the dispersion equation Debye bypassed the introduction of some constant velocity averaged for longitudinal and transverse waves $u$. Thus, expression (2) is reduced to the integral:

$$
U=\frac{12 \pi V k_{B}^{4} T^{4}}{u^{3} h^{3}} \int_{0}^{\theta / T} \frac{x^{3} d x}{e^{x}-1}+N \frac{9}{8} k_{B} \theta,
$$

where the variable $x=h v / k_{B} T$ is entered. The second term in this expression is due to the vacuum energy, or zero vibration modes. The resulting expression agrees well with the experiment in two ranges, $\theta<<T$ and $\theta>>T$, when the assumption made about the form of the dispersion equation turns out to be applicable. In the first case, after approximation of the exponential in the form $e^{x} \approx 1+x$, we obtain for the internal energy and heat capacity of the expression:

$$
U=3 N k_{B} T+\frac{8}{9} k_{B} N \theta, C_{V}=3 N k_{B} .
$$

In the second case, when $\theta>>T$, the upper limit in the integral is replaced by $\infty$ :

$$
\int_{0}^{\infty} \frac{x^{3} d x}{e^{x}-1}=\frac{\pi^{4}}{15}
$$

Accordingly, we obtain:

$$
U=\frac{12 \pi^{5} V k_{B}^{4} T^{4}}{15 u^{3} h^{3}}+N \frac{9}{8} k_{B} \theta, C_{V}=\frac{48 \pi^{5} V k_{B}^{4} T^{3}}{15 u^{3} h^{3}} .
$$

Unlike massive samples, not only the upper limit of possible frequencies and the lower one starts to matter for nanoparticles. Indeed, in principle, elastic waves with a wavelength greater than the size of the crystal itself cannot arise in a crystal. Thus, instead of the expression (4) for nanoparticles, one would have to write

$$
U=\frac{12 \pi V k_{B}^{4} T^{4}}{u^{3} h^{3}} \int_{x_{1}}^{\theta / T} \frac{x^{3} d x}{e^{x}-1}+\frac{6 \pi V^{\theta / T}}{u^{3}} \int_{x_{1}} v^{3} d v,
$$

where $x_{1}=\frac{h v_{\min }}{k_{B} T}=\frac{h u}{k_{B} l T}$ is the lower limit determined by the characteristic size of the nanoparticle $l$. It is convenient to express this expression in the form (9):

$$
U=\frac{12 \pi V k_{B}^{4} T^{4}}{u^{3} h^{3}}\left(\int_{0}^{\theta / T} \frac{x^{3} d x}{e^{x}-1}-\int_{0}^{x_{1}} \frac{x^{3} d x}{e^{x}-1}\right)+\frac{3}{2} \frac{\pi V h}{u^{3}}\left(v_{\max }^{3}-v_{\min }^{3}\right) .
$$

For the analysis it is necessary to make some assumptions about the ratio $T$ and $\theta$. If we assume that $T<<\theta$, but $T \gg>v_{\min } / k_{B}$, then we arrive at the expression

$$
U=\frac{12 \pi^{5} V k_{B}^{4} T^{4}}{15 u^{3} h^{3}}-\frac{12 \pi V k_{B} T v_{\text {miv }}^{3}}{u^{3}}+\frac{3}{2} \frac{\pi V h}{u^{3}}\left(v_{\max }^{3}-v_{\min }^{3}\right) .
$$


For the heat capacity of nanoparticles, we obtain the expression

$$
C_{V}=\frac{48 \pi^{5} V k_{B}^{4} T^{3}}{15 u^{3} h^{3}}-\frac{12 \pi V k_{B} v_{\min }^{3}}{u^{3}} .
$$

Given that you can take $v_{\min }=u / l$, we get

$$
C_{V}=\frac{48 \pi^{5} V k_{B}^{4} T^{3}}{15 u^{3} h^{3}}-\frac{12 \pi V k_{B}}{l^{3}} .
$$

At high temperatures $T \gg \theta$ we get

$$
C_{V}=3 N k_{B}-\frac{12 \pi V k_{B}}{l^{3}} .
$$

However, $V / l^{3} \approx 1$. Consequently, taking into account the existence of a minimum frequency leads to a «subsidence» of the heat capacity of bodies by about $12 \pi k_{B}$.

For massive samples, this value has no practical value. However, for nanoparticles, this amendment contributes. It is easy to see that at high temperatures, it reaches $10 \%$ with the number of atoms in the nanoparticle of the order of 100 .

At temperatures well below the Debye temperature, its relative weight becomes much larger.

Note that the theory used is not a quantum one and does not allow conclusions to be made regarding ultra-low temperatures.

\section{Debye temperature for nanoparticles}

The Debye temperature is derived from the equality of the number of phonons and the number of degrees of freedom of the sample.

$$
\frac{12 \pi V}{u^{3}} \int_{0}^{v_{\max }} v^{2} d v=3 N-6 \approx 3 N
$$

Where we get expressions (3). In the case of nanoparticles, as noted above, this integral should have a lower bound $v_{\min } \approx u / l$. In addition, in view of the relative increase in area relative to volume, the number of degrees of freedom must also be recalculated. Roughly, the number of degrees of freedom of a spherical nanoparticle can be estimated as follows. Let $d$ be the size of the unit cell. Then the ratio of the volume of the surface layer of the nanoparticle $V_{s}$, taken as having a thickness $d$, to its volume:

$$
\frac{V_{s}}{V}=\frac{4 \pi R^{2} d}{(4 / 3) \pi R^{3}}=\frac{3 d}{R}=\frac{N_{s}}{N},
$$

where $N_{s} / N$ is the ratio of the number of atoms on the surface of the nanoparticle to the total number of atoms. If we assume that for atoms of superficiality one of the vibrational degrees of freedom is degenerate (for the time being we neglect «surface phonons»), then the total number of degrees of freedom of nanoparticles will be less by $N_{s}$. For the Debye temperature we have, therefore,

$$
\frac{12 \pi V^{3}}{u^{3}} \int_{v_{\min }}^{v_{\max }} v^{2} d v \approx 3 N-\frac{3 d}{R} N
$$

After integration, we obtain the expressions for $v_{\max }$ and the Debye temperature for nanoparticles

$$
v_{\max }=\sqrt[3]{\frac{3 u^{3} N}{4 \pi V}\left(1-\frac{d}{R}\right)+v_{\min }^{3}}, \theta_{\text {nano }}=\sqrt[3]{\theta^{3}\left(1-\frac{d}{R}\right)+\left(\frac{h}{k_{B}} v_{\min }\right)^{3}} .
$$

Considering that the difference between the orders $v_{\max }$ and $v_{\min }$ is quite significant

$$
\frac{v_{\max }}{v_{\min }} \approx \frac{l}{d} \propto 10^{3}-10^{6},
$$

We can neglect the second term in (17) and accept the expression

$$
\theta_{\text {nano }}=\theta \sqrt[3]{1-\frac{d}{R}}
$$




\section{The thickness of the surface layer of crystals}

In [20], we showed that the thickness of the surface layer of an atomically smooth solid is:

$$
d=0,17 \cdot 10^{-3} \cdot v \text {. }
$$

Equation (20) shows that the thickness of the surface layer of an atomically smooth solid is determined by one parameter - the atomic (molecular) volume of the element, which changes in accordance with the periodic law D.I. Mendeleev.

The values of the parameter $d$ for some metals are given in Table 1. The experimental value for atomically smooth surfaces of gold crystals obtained in the geometry of sliding x-rays is $2.4 \mathrm{~nm}$ [21]. This almost coincides with Table 1.

However, the size dependence of the physical properties of solids begins at $h \approx 10 \mathrm{~d}$.

Equation (19) shows that in coordinates ${ }^{3}\left(\theta_{\text {nano }} / \theta\right)-1 \approx 1 / R$ we get a straight line giving the values of $d$. In Table $1, d$ values can be compared.

For the dimensional dependence of the physical property of a solid $A(r)$, we obtained the relations [22]:

$$
A(r)=A_{0} \cdot\left(1-\frac{d}{r}\right)
$$

Here, $A_{0}$ is equal, in particular, to the melting point $T_{m}$. According to Lindemann [23], when the oscillation amplitude reaches a certain critical (magnitude) fraction of the distance between the equilibrium positions of the atoms, the oscillations begin to interfere with each other.

As a result, the crystal becomes mechanically unstable. For the melting point, he obtained the following expression:

$$
T_{m}=c v_{E} V^{2 / 3} \cdot M=c^{\prime} \cdot \theta^{2} V^{2 / 3} \cdot M,
$$

where $V$ is the molar volume, $M$ is the mass of the atom, $v_{E}$ is the characteristic frequency, $\theta$ is the Debye temperature, $c$ and $c^{\prime}$ are constant, which are assumed to be the same for crystals with similar structures. The verification showed that the Lindemann equation (22) is justified only for metals with the structure of the HCP, FCC and partially BCC. From equation (22) it follows that $T_{m} \sim \theta^{2}$, and from equations (21) and (19) it follows that $T_{m} \sim \theta^{3}$.

Table 1

The thickness of the surface layer of some metals [20]

\begin{tabular}{|c|c||c|c||c|c||c|c||c|c||c|c|}
\hline $\mathrm{M}$ & $d, \mathrm{~nm}$ & $\mathrm{M}$ & $d, \mathrm{~nm}$ & $\mathrm{M}$ & $d, \mathrm{~nm}$ & $\mathrm{M}$ & $d, \mathrm{~nm}$ & $\mathrm{M}$ & $d, \mathrm{~nm}$ & $\mathrm{M}$ & $d, \mathrm{~nm}$ \\
\hline $\mathrm{Li}$ & 0,7 & $\mathrm{Sr}$ & 5,8 & $\mathrm{Sn}$ & 1,4 & $\mathrm{Cd}$ & 1,3 & $\mathrm{Fe}$ & 2.2 & $\mathrm{Gd}$ & 5.3 \\
\hline $\mathrm{Na}$ & 1,5 & $\mathrm{Ba}$ & 6,2 & $\mathrm{~Pb}$ & 1,8 & $\mathrm{Hg}$ & 0,6 & $\mathrm{Co}$ & 2,0 & $\mathrm{~Tb}$ & 5,3 \\
\hline $\mathrm{K}$ & 2,6 & $\mathrm{Al}$ & 1,5 & $\mathrm{Se}$ & 1,3 & $\mathrm{Cr}$ & 2,7 & $\mathrm{Ni}$ & 1,9 & $\mathrm{Dy}$ & 5,3 \\
\hline $\mathrm{Rb}$ & 2,9 & $\mathrm{Ga}$ & 0,6 & $\mathrm{Te}$ & 2,5 & $\mathrm{Mo}$ & 4,6 & $\mathrm{Ce}$ & 3,8 & $\mathrm{Ho}$ & 5,5 \\
\hline $\mathrm{Cs}$ & 3,6 & $\mathrm{In}$ & 1,1 & $\mathrm{Cu}$ & 1,6 & $\mathrm{~W}$ & 5,8 & $\mathrm{Pr}$ & 4,2 & $\mathrm{Er}$ & 5,5 \\
\hline $\mathrm{Be}$ & 1,3 & $\mathrm{Tl}$ & 1,9 & $\mathrm{Ag}$ & 2,2 & $\mathrm{Mn}$ & 2,0 & $\mathrm{Nd}$ & 4,5 & $\mathrm{Tm}$ & 5,2 \\
\hline $\mathrm{Mg}$ & 2,2 & $\mathrm{Si}$ & 3,4 & $\mathrm{Au}$ & 2,3 & $\mathrm{Tc}$ & 3,6 & $\mathrm{Sm}$ & 4,4 & $\mathrm{Yb}$ & 4,6 \\
\hline $\mathrm{Ca}$ & 4,9 & $\mathrm{Ge}$ & 2,8 & $\mathrm{Zn}$ & 1,1 & $\mathrm{Re}$ & 4,6 & $\mathrm{Eu}$ & 5,8 & $\mathrm{Lu}$ & 5,7 \\
\hline
\end{tabular}

In [24], the Lindemann equation was refined:

$$
T_{m}=\frac{m \theta^{2} V^{2 / 3} Z\left(1+\frac{\Delta S_{m}}{2 R}+\frac{\Delta S_{p}}{2 R}\right) \cdot 3 R}{d_{t} c_{p}(1+v) \cdot(1-2 v)^{1 / 2} \cdot(1+\sigma)^{2}} .
$$

From equation (23) it follows that $T_{m} \sim \theta^{2} \sim \theta^{3}$, which is close to equation (19).

In nanomaterials, as shown by experimental data, the Debye temperature decreases in comparison with large-crystalline samples. The reason for this is the change in the form and boundaries of the phonon spectrum of a small crystal. A decrease in the Debye temperature associated with a decrease in particle size has 
been observed in many studies [25]. The dependence of the Debye temperature of small particles on their size is shown in Table 2.

Equation (19), despite its simplicity, shows good agreement with experimental data. In this case, it is necessary to take into account equation (20) that the thickness of the surface layer of an atomically smooth solid is determined by one parameter - the atomic (molecular) volume of the element.

Table 2

\section{Debye temperature dependence of small particles on their size}

\begin{tabular}{|c|c|c|c|}
\hline Metal & $R, \mathrm{~nm}$ & $\begin{array}{c}\theta_{\text {nano }} / \theta, \\
\text { experiment [25] }\end{array}$ & $\begin{array}{c}\theta_{\text {nano }} / \theta, \\
\text { by equation (19) }\end{array}$ \\
\hline $\mathrm{Au}$ & 10 & 0,920 & 0,917 \\
\hline $\mathrm{Ag}$ & 15 & 0,910 & 0,920 \\
\hline $\mathrm{Pb}$ & 6 & 0,830 & 0,836 \\
\hline $\mathrm{V}$ & 6,5 & 0,860 & 0,858 \\
\hline
\end{tabular}

The Debye temperature divides the temperature scale into two regions: low-temperature, where not all frequencies of the lattice vibration spectrum are excited, and high-temperature, where all frequencies are excited. This division is arbitrary, since the transition from one region to another in a three-dimensional crystal is not sharp. The crystal size (in the one-dimensional case, the length of the atomic chain $L$ ) determines the wavelengths $\lambda_{j}$ of the excitations. The energy produced by the excitation at a length $\lambda_{j}$ depends on the number of excitation photons at this wavelength. The number of quanta is related to the magnitude of the exciting factor, for example, to temperature. The energy of a single quantum depends on both $\lambda_{j}$ and the lattice parameters.

\section{Conclusion}

In general, the described approach is quite obvious and there is a large number of its variations. However, comparison with experimental data for all variations of this formula is rather qualitative. The problem, apparently, consists in significant abstraction of the task. The studied nanoparticles do not have an ideal spherical shape and uniform size. This circumstance should introduce significant errors.

The work was performed under the program of the MES RK. Grants № $0118 P K 000063$ and № O.0781.

\section{References}

1 Wolf E.L. Nanophysics and Nanotechnology: An Introduction to Modern Concepts in Nanoscience / E.L. Wolf. - WileyVCH: Weinheim, Germany, 2004. - 174 p.

2 Dupas C. Nanoscience: Nanotechnologies and Nanophysics / C. Dupas, P. Houdy, M. Lahmani (Eds.). - Springer-BerlinHeidelberg-New York, 2007. - 823 p.

3 Sattler K.D. Handbook of Nanophysics: Nanoelectronics and Nanophotonics / K.D. Sattler. — CRC Press, 2011. — 780 p.

4 Raz J. Nanoparticles / J. Raz. — Berlin; Walter de Gruyter GmbH \& Co., KG, 2015. — 283 p.

5 Rogers B. Nanotechnology: understanding small systems / B. Rogers, J. Adams, S. Pennathur. - Boca Raton: CRC Press, Taylor \& Francis Group, 2015. - 407 p.

6 Ngo Ch. Our nanotechnology future / Ch. Ngo, J.B. Natowitz. - Chicago: University of Chicago Press, 2017. - 243 p.

7 Mokkapati S. Nanowires for energy applications / S. Mokkapati, Ch. Jagadish. — Cambridge, MA: Academic Press, 2018. $-536 \mathrm{p}$.

8 Roy S. Nanotechnology: synthesis to applications / S. Roy, Ch.K. Ghosh, Ch.K. Sarkar. — Boca Raton, FL: CRC Press, Taylor \& Francis Group, 2018. - 328 p.

9 Fraune M. Size dependence of the exchange bias field in NiOXNi nanostructures / M. Fraune, U. Reudiger, G. Geuntherod // Applied Physics Letters. - 2000. — Vol. 77. — No. 23. - P. 3815-3817.

10 Sun Ch.Q. Size dependence of nanostructures: Impact of bond order deficiency / Ch.Q. Sun // Progress in Solid State Chemistry. - 2007. - Vol. $35-$ P. 1-159.

11 Liu X.J. Correlation and size dependence of the lattice strain, binding energy, elastic modulus, and thermal stability for Au and Ag nanostructures / X.J. Liu, Z.F. Zhou, L.W. Yang, J.W. Li, G.F. Xie, S.Y. Fu, Ch.Q. Sun. // Appl. Phys. — 2011. — Vol. 109. - P. 1-5.

12 Albanese A. The Effect of Nanoparticle Size, Shape, and Surface Chemistry on Biological Systems / A. Albanese, P.S. Tang, W.C.W. Chan. // Annu. Rev. Biomed. Eng. - 2012. - Vol. 14. - P. 1-16. 
13 Mikhailin N.Yu. Size Dependences of the Magnetic Properties of Superconducting Lead-Porous Glass Nanostructures / N.Yu. Mikhailin, D.V. Shamshur, R.V. Parfen'ev, V.I. Kozub, Yu.M. Gal'perin, Yu.A. Kumzerov, A.V. Fokin. // Physics of the Solid State. - 2018. - Vol. 60, No. 6. - P. 1068-1072.

14 Андриевский Р.А. Размерные эффекты в нанокристаллических материалах. І. Особенности структуры. Термодинамика. Фазовые равновесия. Кинетические явления / Р.А. Андриевский, А.М. Глезер. // Физика металлов и металловедение. - 1999. - Т. 88, № 1. - С. 50-73.

15 Щербаков Л.М. О статистической оценке избыточной свободной энергии малых объектов в термодинамике микрогетерогенных систем / Л.М. Щербаков // Доклады АН СССР. — 1966. — Т. 168, № 2. — С. 388-391.

16 Уваров Н.Ф. Размерные эффекты в химии гетерогенных систем / Н.Ф. Уваров, В.В. Болдырев. // Успехи химии. 2001. - T. 70. - C. 307-329.

17 Tringides M.C. Quantum size effects in metallic nanostructures / M.C. Tringides, M. Jatochowski, E. Bauer. // Physics Today. - 2007. - Vol. 60, No. 4. - P. 50-54.

18 Арутюнов К.Ю. Квантовые размерные эффекты в металлических наноструктурах / Н.Ю. Арутюнов // ДАН ВШ РАН. - 2015. - № 3(28). - C. 7-16.

19 Ziman J.M. Electrons and phonons / J.M. Ziman. - Oxford Univer. Press, London, 1960. - 268 p.

20 Юров В.М. Толщина поверхностного слоя, поверхностная энергия и атомный объем элемента / В.М. Юров, С.А. Гученко, В.Ч. Лауринас // Физико-химические аспекты изучения кластеров, наноструктур и наноматериалов. - Тверь: Твер. гос. ун-т, - 2018. - Вып. 10. - С. 691-699.

21 Guo J. X-Rays in Nanoscience: Spectroscopy, Spectromicroscopy, and Scattering Techniques / J. Guo. - Wiley-VCH, Verlag, 2010. - $263 \mathrm{p}$.

22 Юров В.М. Размерные эффекты и поверхностное натяжение чистых металлов / В.М. Юров, В.Ч. Лауринас, С.А. Гученко, О.Н. Завацкая // Успехи современного естествознания. — 2012. — № 7. — С. 88-93.

23 Lindemann F.A. The calculation of molecular vibration frequencies / F.A. Lindemann. // Physik. Z. — 1910. — Vol. 11. — P. 609-612.

24 Сачавский А.Ф. Единое уравнение состояния вещества / А.Ф. Сачавский, В.В. Евстигнеев, Н.А. Сачавская // Тр. АлтГТУ им. И.И. Ползунова. - Барнаул, 1998. - Вып. 8. - С. 214-222.

25 Анциферова И.В. Зависимость процесса уплотнения при спекании с использованием наноразмерных металлических порошков / И.В. Анциферова // Вестн. ПНИПУ. - 2015. - Т. 17, № 2. - С. 13-20.

В.М. Юров, В.В. Архипов, Г.А. Ранова, В.Ч. Лауринас

\title{
Нанобөлшектердің термодинамикалық сипаттамаларының мөлшеріне тәуелділіктерін зерттеу
}

\begin{abstract}
Мақалада термодинамикалық сипаттамалардың ауытқуларының теориялық сипаттамасына қатысты кейбір көзқарастар, мысалы, жылусыйымдылығы және нанобөлшектер үшін Дебай температурасы қарастырылған. Нанобөлшектер үшін айтарлықтай салмағы бар беткі құбылыстарды есепке алу үшін оны жаңғырту үшін көлемді кристалдық денелердің жылусыйымдылығына арналған Дебайдың стандартты шығарылымы зерттелді. Көлемді үлгілерден айырмашылығы, нанобөлшектер үшін мүмкін жиіліктердің жоғарғы шегі ғана емес, төменгі шегі де маңызды. Шындығында, кристалдың мөлшерінен асатын толқын ұзындығы бар серпімді толқындар кристалда пайда болмайды. Алынған теңдеу атомарлы тегіс қатты беттік қабатының қалыңдығын бір параметрмен - Д.И. Менделеевтің периодтық заңына сәйкес өзгерту элементтің атомдық (молекулалық) көлемімен - анықталатынын көрсетеді. Қорытынды теңдеудің қарапайым түріне қарамастан, эксперименттік деректермен жақсы келісілетіні көрсетілді.
\end{abstract}

Кілт сөздер: жылусыйымдылық, Дебай температурасы, наноқұрылым, кристалл, атомдық көлем.

\section{В.М. Юров, В.В. Архипов, Г.А. Ранова, В.Ч. Лауринас \\ Исследование размерных зависимостей термодинамических характеристик наночастиц}

В статье рассмотрены некоторые подходы к теоретическому описанию отклонений термодинамических характеристик, таких как теплоемкость и температура Дебая для наночастиц. Исследован стандартный вывод Дебая для теплоемкости массивных кристаллических тел на предмет его модернизации для учета поверхностных явлений, имеющих для наночастиц значительный вес. В отличие от массивных образцов для наночастиц начинает иметь значение не только верхний предел возможных частот, но и нижний. Действительно, в кристалле не могут возникать упругие волны с длиной волны больше размера самого кристалла. Полученное уравнение показывает, что толщина поверхностного слоя атомарно-гладкого твердого тела определяется одним параметром - атомным (молекулярным) объемом элемента, изменяющемся в соответствии с периодическим законом Д.И. Менделеева. Урав- 
нение в окончательном виде, несмотря на простоту, показывает хорошее согласие с экспериментальными данными.

Ключевые слова: теплоемкость, температура Дебая, наноструктура, кристалл, атомный объем.

\section{References}

1 Wolf, E.L. (2004). Nanophysics and Nanotechnology: An Introduction to Modern Concepts in Nanoscience. Wiley-VCH: Weinheim, Germany.

2 Dupas, C., Houdy, P., \& Lahmani M. (Eds.) (2007). Nanoscience: Nanotechnologies and Nanophysics. Springer-BerlinHeidelberg-New York.

3 Sattler, K.D. (2011). Handbook of Nanophysics: Nanoelectronics and Nanophotonics. CRC Press.

4 Raz, J. (2015). Nanoparticles. Berlin; Walter de Gruyter GmbH \& Co., KG.

5 Rogers, B., Adams, J., \& Pennathur, S. (2015). Nanotechnology: understanding small systems. Boca Raton: CRC Press, Taylor\&Francis Group.

6 Ngo, Ch. \& Natowitz, J.B. (2017). Our nanotechnology future. Chicago: University of Chicago Press.

7 Mokkapati, S., \& Jagadish, Ch. (2018). Nanowires for energy applications. Cambridge, MA: Academic Press.

8 Roy, S., Ghosh, Ch.K., \& Sarkar, Ch.K. (2018). Nanotechnology: synthesis to applications. Boca Raton, FL: CRC Press, Taylor\&Francis Group.

9 Fraune, M., Reudiger, U., \& Geuntherod, G. (2000). Size dependence of the exchange bias field in NiOXNi nanostructures. Applied Physics Letters, 77, 23, 3815-3817.

10 Sun, Ch.Q. (2007). Size dependence of nanostructures: Impact of bond order deficiency. Progress in Solid State Chemistry, $35,1-159$.

11 Liu, X.J., Zhou, Z.F., Yang, L.W., Li, J.W., Xie, G.F., \& Fu, S.Y. et al. (2011). Correlation and size dependence of the lattice strain, binding energy, elastic modulus, and thermal stability for Au and Ag nanostructures. J. Appl. Phys., 109, 1-5.

12 Albanese, A., Tang, P.S. \& Chan, W.C.W. (2012). The Effect of Nanoparticle Size, Shape, and Surface Chemistry on Biological Systems. Annu. Rev. Biomed. Eng., 14, 1-16.

13 Mikhailin, N.Yu., Shamshur, D.V., Parfen'ev, R.V., Kozub, V.I., Gal'perin, Yu.M., \& Kumzerov, Yu.A. et al. (2018). Size Dependences of the Magnetic Properties of Superconducting Lead-Porous Glass Nanostructures. Physics of the Solid State, 60, 6 , $1068-1072$.

14 Andrievskii, R.A., \& Glezer, A.M. (1999). Razmernye effekty v nanokristallicheskikh materialakh. I. Osobennosti struktury. Termodinamika. Fazovye ravnovesiia. Kineticheskie yavleniia [Size effects in nanocrystalline materials. I. Features of the structure. Thermodynamics. Phase equilibria. Kinetic phenomena]. Fizıka metallov i metallovedenie - Metal Physics and Metallography, 88, 1, 50-73 [in Russian].

15 Sherbakov, L.M. (1966). O statisticheskoi otsenke izbytochnoi svobodnoi enerhii malykh obektov v termodinamike mikroheterohennykh sistem [On the statistical evaluation of the excess free energy of small objects in the thermodynamics of microheterogeneous systems]. Doklady AN SSSR - Reports of the USSR Academy of Sciences, 168, 2, 388-391 [in Russian].

16 Uvarov, N.F., \& Boldyrev, V.V. (2001). Razmernye effekty v khimii heterohennykh sistem [Size effects in the chemistry of heterogeneous systems] Uspekhi khimii - Chemistry advances, 70(4), 307-329 [in Russian].

17 Tringides, M.C., Jatochowski, M., \& Bauer, E. (2007). Quantum size effects in metallic nanostructures. Physics Today, 60, 4, $50-54$.

18 Arutiunov, K.Yu. (2015). Kvantovye razmernye effekty v metallicheskikh nanostrukturakh [Quantum size effects in metallic nanostructures]. DAN VSh RAN - DAN Higher School of Sciences, 3(28), 7-16 [in Russian].

19 Ziman, J.M. (1960). Electrons and phonons. Oxford Univer. Press, London.

20 Yurov, V.M., Guchenko, S.A., \& Laurnnas, V.Ch. (2018). Tolshchina poverkhnostnoho sloia, poverhnostnaia enerhiia i atomnyi obem elementa [The surface layer thickness, surface energy and atomic volume of the element]. Fiziko-khimicheskie aspekty izucheniia klasterov, nanostruktur i nanomaterialov - Physico-chemical aspects of the study of clusters, nanostructures and nanomaterials. Tver: Tver State Univ. Publ., 10, 691-699 [in Russian].

21 Guo, J. (2010). X-Rays in Nanoscience: Spectroscopy, Spectromicroscopy, and Scattering Techniques. Wiley-Vch, Verlag.

22 Yurov, V.M., Laurinas, V.Ch., Guchenko, S.A., \& Zavatskaia, O.N. (2012). Razmernye effekty i poverkhnostnoe natiazhenie chistykh metallov [Dimensional effects and surface tension of pure metals]. Uspekhi sovremennoho estestvoznaniia - Successes of modern science, 7, 88-93 [in Russian].

23 Lindemann, F.A. (1910). The calculation of molecular vibration frequencies. Physik. Z., 11, 609-612.

24 Sachavskii, A.F., Evstihneev, V.V., \& Sachavskaia, N.A. (1998). Edinoe uravnenie sostoianiia veshchestva [Unified equation of state of matter] Trudy AltGTU im. I.I. Polzunova, Barnaul - Works AltSTU. I.I. Polzunov, Barnaul, 8, 214-222 [in Russian].

25 Antsiferova, I.V. (2015). Zavisimost protsessa uplotneniia pri spekanii s ispolzovaniem nanorazmernykh metallicheskikh poroshkov) [The dependence of the compaction process during sintering using nanoscale metal powders]. Vestnik PNIPU - Bulletin of PNIPU, 17, 2, 13-20 [in Russian]. 